\title{
GLYPHOSATE MINERALIZATION: EFFECT OF TEMPERATURE AND SOYBEAN AND CORN CROP RESIDUES
}

\author{
Ariel Rampoldi ${ }^{1}$ *, Susana Hang ${ }^{1}$, Enrique Barriuso ${ }^{2}$
}

\begin{abstract}
A B S T R A C T
Mineralization is the main mechanism of dissipation of glyphosate herbicide (N-[phosphonomethyl] glycine) in soil. However, there is scarce information about the mineralization process in strata formed by stubbles in no-tillage systems. The kinetics and rate of mineralization of herbicide in stubbles of soybean (Glycine $\max$ L. Merr.) and corn (Zea mays L.) were investigated. To evaluate the effect of age of crop residues, samples of soybean stubbles were collected immediately after harvest (Soja 1) and four months after harvest (Soja 2). Corn crop residues were collected three months after harvest. Glyphosate evolution and total microbial activity (TMA) were monitored by release of ${ }^{14} \mathrm{C}-\mathrm{CO}_{2}$ and $\mathrm{C}-\mathrm{CO}_{2}$ under laboratory conditions with two temperatures, 15 and $28{ }^{\circ} \mathrm{C}$. Crop residues size was evaluated using grinding $(1 \mathrm{~mm})$ and cut $(1$ to $2 \mathrm{~cm})$ stubbles. Results showed that glyphosate mineralization was affected by the incubation temperature and the origin and age of crop residues. Size of crop residues did not modify glyphosate mineralization. Average glyphosate mineralization after 56 days of incubation at 15 and $28^{\circ} \mathrm{C}$ was of 3.9 and $9.9 \%$, respectively, of the ${ }^{14} \mathrm{C}$-glyphosate initially applied. In corn crop residues the percentages were 2.0 and $3.0 \%$, respectively, at 15 and $28{ }^{\circ} \mathrm{C}$. A similar evolution was detected for TMA. The co-metabolic nature of glyphosate mineralization was corroborated. An inverse relation between $\mathrm{C} / \mathrm{N}$ ratio and glyphosate mineralization was detected. Higher glyphosate mineralization was detected in fresh soybean stubbles, suggesting that applications on aged crop residues could increase the persistence of glyphosate in notillage systems.
\end{abstract}

Key words: glyphosate, stubbles, mineralization, nontillage system, total microbial activity.

\section{INTRODUCTION}

Glyphosate (N-[phosphonomethyl] glycine) is a non-selective wide spectrum herbicide and the most used in Argentina (CASAFE, 2005). This herbicide considered as of minimum or no risk for agronomic crops is rapidly inactivated in soil. Initially highenergy retention processes explained its inactivation (Piccolo et al., 1994; de Jonge et al., 2001), and the degradation by soil microorganisms was considered as another important means of elimination (Araujo et al., 2003).

Direct sowing introduces an extra component in the analysis of the performance of glyphosate: the presence of crop residues (stubbles) upon the soil, where glyphosate can remain for variable periods. The affinity between glyphosate and plant residues is markedly lower than that in soil (Accinelli et al., 2005), this becomes crucial for potential environmental risks such as surface runoff of the herbicide towards watercourses.

Glyphosate degradation is performed by a non-specific co-metabolic microbial population (Accinelli et al., 2005) similar to the degradation of crop residues, so the factors conditioning transformations of plant residues also affect the persistence of glyphosate accumulated on them. The main factors affecting this process are temperature, humidity, $\mathrm{pH}$ (Schomberg et al., 1994; De-Neve et al., 1996) origin, age and size of plant residues (Angers and Recous, 1997; Kumar and Goh, 2000).

Herbicide degradation and mineralization processes occur mainly in the extractable fraction (Johnson

\footnotetext{
${ }^{1}$ Universidad Nacional de Córdoba, Facultad de Ciencias Agropecuarias, CC 509, Av. Valparaíso s/n, (5000) Córdoba, Argentina. E-mail: arampol@agro.uncor.edu *Corresponding author.

${ }^{2}$ Institut National de la Recherche Agronomique-AgroParisTech - Unité Mixte de Recherche Environnement et Grandes Cultures, 78850 Thiverval-Grignon, France. E-mail: barriuso@grignon.inra.fr 
et al., 1999). On the other hand, the soluble and structural components of plant residues vary in relation to the time and the species (Cordone, 1998; Morón, 2001), which may change the nature of the interactions with glyphosate herbicides. Applications of glyphosate on particular stubble at different fallow times will find a plant residue with different (chemical and biochemical) composition characteristics and the magnitude of the glyphosate degradation process will depend on them.

The aim of this work was to assess the mineralization of glyphosate on soybean and maize stubble. as related to the age and size of harvest residues incubated at two temperatures.

\section{MATERIALS AND METHODS}

\section{Stubble}

The experiment was conducted in the Soil Laboratory of Institut National de la Recherche Agronomique, Francia, AgroParisTech, Unité Mixte de Recherche Environnement et Grandes Cultures, Thiverval-Grignon, Francia (48 $50^{\circ}$ N, $\left.1^{\circ} 56^{\prime} \mathrm{W}\right)$. Two crop stubbles were sampled: soybean and maize. Soybean stubble was sampled twice, immediately (Soybean 1) and four months after harvest (Soybean 2). Corn stubble (Corn) were sampled three months after harvest. The stubble was dried at $60{ }^{\circ} \mathrm{C}$ for $72 \mathrm{~h}$. One part was ground to $1 \mathrm{~mm}$ using a mesh adjustable forage grinding mill (5657 HAAN, Retschmühle, Germany) and another was cut with scissors from 1 to $2 \mathrm{~cm}$ maintaining stem/ leaf proportions. Total organic carbon (TOC) was determined by dry combustion at $580{ }^{\circ} \mathrm{C}$ and total nitrogen (Nt) by Kjeldahl (Table 1).

\section{Glyphosate solution}

Glyphosate marked in the phosphonomethyl group carbon atom (specific activity $=81.5 \mathrm{MBq} \mathrm{mmol}^{-1}$, 99.2\% purity) was used. Sigma Chemicals (St. Louis, Missouri, USA) provided the ${ }^{14} \mathrm{C}$-glyphosate. The final concentration of the aqueous glyphosate solution was $26.2 \mathrm{mg} \mathrm{L}^{-1}$ and $1.3 \times 10^{7} \mathrm{~Bq} \mathrm{~L}^{-1}$.

\section{Evolution of ${ }^{14} \mathrm{C}$-glyphosate $\left({ }^{14} \mathrm{C}-\mathrm{CO}_{2}\right)$ and oxi- dizable carbon $\left(\mathrm{C}-\mathrm{CO}_{2}\right)$}

Three replicates of each sample were incubated in a hermetic glass container for 56 days at 15 and $28 \pm 1$ ${ }^{\circ} \mathrm{C}$ in darkness. To $1 \mathrm{~g}$ of stubble was added $0.5 \mathrm{~mL}$ of glyphosate solution, adjusting moisture to $85 \% \mathrm{w} / \mathrm{w}$ with water Milli-Q (Millipore, Bellerica, Massachusetts, USA). The $\mathrm{C}-\mathrm{CO}_{2}$ and ${ }^{14} \mathrm{C}-\mathrm{CO}_{2}$ released during the incubation were recovered in $5 \mathrm{~mL}$ of $2 \mathrm{M}$ $\mathrm{NaOH}$ solution. $\mathrm{NaOH}$ was extracted at $3,7,14,21$, $28,35,42,49$ and 56 days and replaced. C- $\mathrm{CO}_{2}$ was analyzed colorimetrically using a continuous flow analyzer (Skalar, Breda, The Netherlands) and the ${ }^{14} \mathrm{C}-\mathrm{CO}_{2}$ was determined by a liquid scintillation counter (Packard Instruments, Tri-Carb 2100 TR, Meridien, Connecticut, USA), using $10 \mathrm{~mL}$ of scintillation cocktail (Ultima Gold XR Packard Instruments).

\section{Statistical analysis}

To determine the effect of stubble origin on the variables oxidizable carbon $\left(\mathrm{C}-\mathrm{CO}_{2}\right)$ and ${ }^{14} \mathrm{C}$-mineralized glyphosate $\left({ }^{14} \mathrm{C}-\mathrm{CO}_{2}\right)$, a variance analysis (ANOVA) of four factors with factor interaction was performed. The factors were origin (two levels: soybean and maize), age (two levels: Soybean 1 and Soybean 2), size (two levels: ground and cut) and temperature (two levels: 15 and $28{ }^{\circ} \mathrm{C}$ ). Verification tests corresponding to the assumptions of normality, independence and homogeneity of the variance of residuals were performed, accepting the null hypothesis in all cases.

Mean differences were analyzed by the Least Significant Difference (LSD) test $(\mathrm{P} \leq 0.01)$. To determine relations between variables, a correlation analysis between the plant residues chemical parameters, total microbial activity and percentage of total ${ }^{14} \mathrm{C}$-glyphosate mineralized at 56 days was performed. The data were analyzed using the statistical InfoStat (2006) software.

Table 1. Elemental characterization of soybean and maize crop residues. Glyphosate mineralization trial.

\begin{tabular}{lccr}
\hline Characteristics & Soybean 1 & Soybean 2 & Corn \\
\hline Total organic carbon, $\mathrm{g} \mathrm{kg}^{-1}$ & 381 & 394 & 384 \\
Total nitrogen, g kg-1 & 7.0 & 5.8 & 3.3 \\
Relation carbon/nitrogen & $54: 1$ & $68: 1$ & $116: 1$ \\
\hline
\end{tabular}

Soybean 1: stubble sampled immediately after harvest; Soybean 2: stubble sampled 4 months after harvest. 


\section{RESULTS AND DISCUSSION}

\section{Carbon mineralization in stubbles}

Oxidizable carbon kinetics as estimation of total microbial activity (TMA) and mineralization rate are shown in Figure 1. Highest TMA at 56 days of incubation was observed for Soybean 1 stubble, and the lowest for Corn. Soybean 2 stubble presented an intermediate TMA between Soybean 1 and Corn. Differences in elementary composition (C and $\mathrm{N})$ and the relationship between both elements adequately explained the differences found. A higher content of $\mathrm{N}$ favored TMA $(\mathrm{r}=0.62, \mathrm{p}<0.00001)$ and the opposite was observed for carbon content $(\mathrm{r}=-0.59$, $\mathrm{p}<0.0001)$ and $\mathrm{C} / \mathrm{N}(\mathrm{r}=-0.60, \mathrm{p}<0.00001)$, corroborating the stimulating effect of $\mathrm{N}$ on microbial activity (Jama and Nair, 1996).

The percentage of oxidizable carbon (mineralized $\mathrm{C}-\mathrm{CO}_{2}$ ) for the total carbon in the three residues, after 56 days and at $15{ }^{\circ} \mathrm{C}$ was $19.2 \pm 5 \%$, while at $28{ }^{\circ} \mathrm{C}$ it was $22.6 \pm 4 \%$ (Table 2), confirming that the higher temperature increases microbial activity (Collins et al., 1990).

When incubated at $28{ }^{\circ} \mathrm{C}$, the mineralization of oxidizable carbon in Soybean 2 stubble was significantly higher $(\mathrm{P} \leq 0.01)$ on ground stubble as compared to the cut residues. Grinding the stubble increased the contact surface and generated greater accessibility of microorganisms to substrate (Sorensen et al., 1996; Angers and Recous, 1997) increasing the mineralization of organic carbon on stubble. At the same time microorganism activity is stimulated by temperature (Collins et al., 1990; Paul and Clark, 1996), partly explaining the increase of organic carbon mineralization in Soybean 2 stubble ground and incubated at $28^{\circ} \mathrm{C}$. The lack of differences due to the size of the residues in Soybean 1 incubated at $28^{\circ} \mathrm{C}$ shows that the fresh stubble condition eliminates the size effect, as previous research had reported (Douglas and Rickman, 1992).

The opposite was observed for corn, where the grinding treatment showed less microbial attack than the cutting treatment at both incubation temperatures, revealing the limitations of the elementary components as indicators of stubble behavior. It is considered that a high content of lignin and phenols can act as inhibitors of microbial activity (Kumar and Goh, 2000), explaining in part, the lower TMA in ground stubble due to a greater exposure to those substances.

\section{Mineralization of glyphosate in stubble}

The kinetics and rate of mineralization of ${ }^{14} \mathrm{C}$-glyphosate in soybean stubble (Soybean 1 and Soybean 2) as well as in corn is shown in Figure 2. The average ${ }^{14} \mathrm{C}-\mathrm{CO}_{2}$ released at the end of glyphosate

Table 2. Oxidizable carbon $\left(\mathrm{C}-\mathrm{CO}_{2}\right)$ and mineralized glyphosate $\left({ }^{14} \mathrm{C}-\mathrm{CO}_{2}\right)(\%)$ after 56 days as regards origin, age, temperature of incubation and size of crop residues.

\begin{tabular}{|c|c|c|c|c|}
\hline \multirow[t]{2}{*}{ Stubble } & \multirow[t]{2}{*}{ Temperature $\left({ }^{\circ} \mathrm{C}\right)$} & \multirow[t]{2}{*}{ Size } & $\begin{array}{c}\text { Oxidizable } \\
\text { carbon }\left(\mathrm{C}-\mathrm{CO}_{2}\right)\end{array}$ & $\begin{array}{l}\text { Mineralized glyphosate } \\
\qquad\left({ }^{14} \mathrm{C}-\mathrm{CO}_{2}\right)\end{array}$ \\
\hline & & & \multicolumn{2}{|r|}{$\%$} \\
\hline Soybean 1 & $\begin{array}{l}15 \\
28\end{array}$ & $\begin{array}{l}\text { Ground } \\
\text { Cut } \\
\text { Ground } \\
\text { Cut }\end{array}$ & $\begin{array}{l}23.1 \pm 0.7 \mathrm{bcd} \\
21.3 \pm 1.0 \mathrm{def} \\
26.1 \pm 0.6 \mathrm{a} \\
25.9 \pm 0.9 \mathrm{a}\end{array}$ & $\begin{aligned} 4.9 & \pm 0.8 \mathrm{~cd} \\
3.7 & \pm 0.6 \mathrm{de} \\
13.3 & \pm 2.0 \mathrm{a} \\
11.1 & \pm 2.0 \mathrm{a}\end{aligned}$ \\
\hline Soybean 2 & $\begin{array}{l}15 \\
28\end{array}$ & $\begin{array}{l}\text { Ground } \\
\text { Cut } \\
\text { Ground } \\
\text { Cut }\end{array}$ & $\begin{array}{l}21.8 \pm 0.6 \mathrm{cde} \\
19.6 \pm 0.8 \mathrm{ef} \\
24.8 \pm 1.3 \mathrm{ab} \\
19.2 \pm 1.2 \mathrm{f}\end{array}$ & $\begin{array}{l}3.7 \pm 0.5 \mathrm{de} \\
3.3 \pm 0.6 \mathrm{de} \\
8.6 \pm 1.0 \mathrm{~b} \\
6.5 \pm 1.4 \mathrm{bc}\end{array}$ \\
\hline Corn & $\begin{array}{l}15 \\
28\end{array}$ & $\begin{array}{l}\text { Ground } \\
\text { Cut } \\
\text { Ground } \\
\text { Cut }\end{array}$ & $\begin{array}{c}9.8 \pm 0.3 \mathrm{~h} \\
19.6 \pm 2.0 \mathrm{ef} \\
15.3 \pm 0.6 \mathrm{~g} \\
24.1 \pm 1.8 \mathrm{abc}\end{array}$ & $\begin{array}{l}2.2 \pm 0.4 \mathrm{e} \\
1.9 \pm 0.6 \mathrm{e} \\
3.2 \pm 0.4 \mathrm{de} \\
3.0 \pm 0.6 \mathrm{de}\end{array}$ \\
\hline
\end{tabular}

Different letters indicate significant differences according to least significant difference test (LSD) (P $<0.01)$.

Soybean 1: stubble sampled immediately after harvest; Soybean 2: stubble sampled 4 months after harvest. 

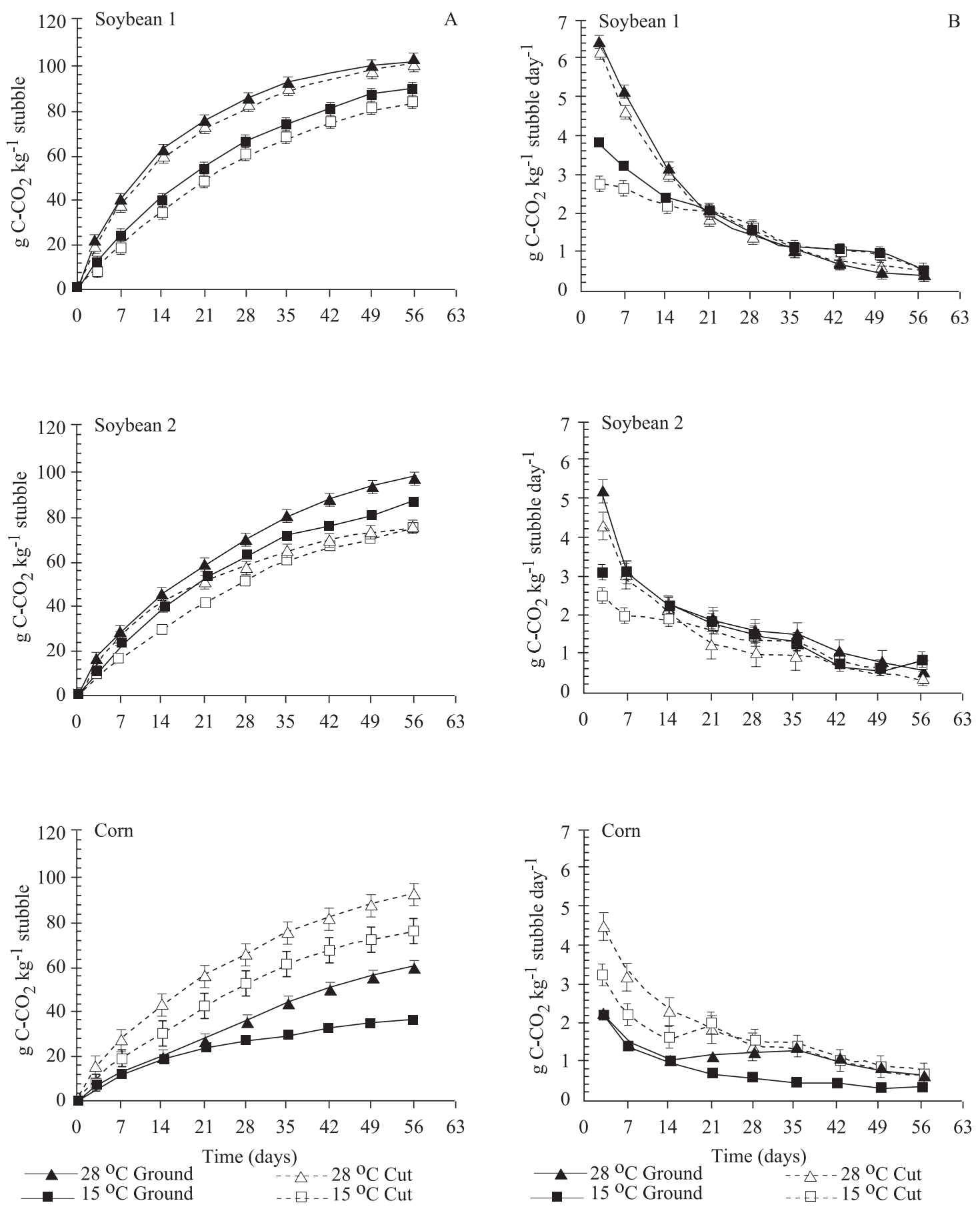

Figure 1. Kinetics (A) and mineralization rates (B) of oxidizable carbon in soybean and corn crop residues. Incubations were carried out at 15 and $28^{\circ} \mathrm{C}$ with Ground $(1 \mathrm{~mm})$ and $\mathrm{Cut}(1 \mathrm{to} 2 \mathrm{~cm})$ residues. 
incubation was $8.3 \%$ (Soybean 1), 5.5\% (Soybean 2) and $2.6 \%$ (Corn) coming out from the initial ${ }^{14} \mathrm{C}$ glyphosate, differing significantly $(\mathrm{P} \leq 0.01)$ (Table 2). An inverse relationship was observed between ${ }^{14} \mathrm{C}$-glyphosate and $\mathrm{C} / \mathrm{N}$ (Figure 3), indicating that stubble composition determines the degree of glyphosate mineralization on them.

The stimulating effect of temperature on degradation of ${ }^{14} \mathrm{C}$-glyphosate was verified and consistent with previous studies (Eberbach, 1999; StrangeHansen et al., 2004). The mineralization rate was highest on the third day for all stubbles when incubation was conducted at $15{ }^{\circ} \mathrm{C}$, while at $28{ }^{\circ} \mathrm{C}$ glyphosate mineralization rate was maximum in soybean stubble at day 7 of incubation, and at day 3 in corn stubble. Previous studies confirm the presence of a variable delay phase. Franz et al. (1997) did not find a delay phase in soils contrary to Mamy (2004) who worked with plant material. This difference in the results suggest that the occurrence of a phase of adaptation of microorganisms is a function of the type of material and not of the kind of microorganisms, as it happens with atrazine (Bollag et al., 1992). However, the highest mineralization rate of oxidizable carbon (day 3 ) at $28{ }^{\circ} \mathrm{C}$ in soybean stubble was not reflected in an increase of glyphosate mineralization rate at the same period. This suggests that factors as temperature and stubble quality, which allows microorganisms to express their maximum degradation potential (Collins et al., 1990; Douglas and Rickman, 1992; Tian et al., 1995), not necessarily increase the glyphosate mineralization rate in the first days of herbicide application, because of the preference of microorganisms for the carbon substrate of stubble instead of glyphosate.

Mineralization of glyphosate showed a similar evolution to that of TMA (Soybean $1>$ Soybean $2>$ Corn), although the differences between origin of stubble and treatment were lower in glyphosate. One positive and significant correlation between percentage of oxidizable carbon (56 days) and percentage of ${ }^{14} \mathrm{C}$-glyphosate (56 days) confirms that glyphosate is degraded by nonspecific microflora (Accinelli et al., 2005) $(\mathrm{r}=0.66, \mathrm{P}<0.001)$. The total amount of ${ }^{14} \mathrm{C}$-glyphosate released from Soybean 1 suggests that applications of herbicide immediately after harvest would be less persistent than applications over older stubbles or residues with a higher proportion of lignin, as Soybean 2.
On the average, the mineralization of glyphosate applied to the soybean stubble and incubated at 15 ${ }^{\circ} \mathrm{C}$ for a period of 56 days was $3.9 \%$ of the initial dose applied and $9.9 \%$ when incubated at $28{ }^{\circ} \mathrm{C}$, whereas for corn stubble was 2.0 and $3.0 \%$, respectively. That is, the decrease in the proportion of mineralized glyphosate was 65,55 and $34 \%$, for Soybean 1, Soybean 2 and Corn, respectively, when incubation was done at $15{ }^{\circ} \mathrm{C}$. However, the effect of temperature on glyphosate mineralization in corn stubble was not significative. The absence of differences in glyphosate mineralization in corn stubble due to the effect of temperature, suggests that the microorganisms population degrading corn stubble has low affinity for glyphosate, increasing the permanence period of the herbicide on this stubble.

The effect of material size on glyphosate mineralization was evaluated for each stubble, as this factor varies throughout the year and depends on the origin of material (Angers and Recous, 1997). Glyphosate mineralization in plant residues was not affected by material size. While the percentages of mineralized glyphosate were higher in ground materials as compared to cut materials, these differences were not significant $(\mathrm{P} \leq 0.01)$, indicating that the changes in physical structure which stubble may experience through time do not change the level of mineralized glyphosate.

\section{CONCLUSIONS}

Glyphosate mineralization was modified by incubation temperature, the origin of plant residues and stubble age in the case of soybean, but was not affected by the particle size of treated stubble. On the average, 3.9 and $9.9 \%$ of glyphosate initially applied to soybean stubble was mineralized after 56 days of incubation at 15 and $28^{\circ} \mathrm{C}$, respectively, while corn residue mineralization was of 2.0 and $3.0 \%$ at the same temperatures. A similar behavior on the evolution of TMA was observed confirming the co-metabolic nature of glyphosate mineralization. An inverse relationship was detected between $\mathrm{C} / \mathrm{N}$ and the proportion of mineralized glyphosate. TMA was more active in newer than in older soybean residues and therefore increased glyphosate mineralization, suggesting that applications of the herbicide on older stubble could increase its persistence in cover farming systems. 

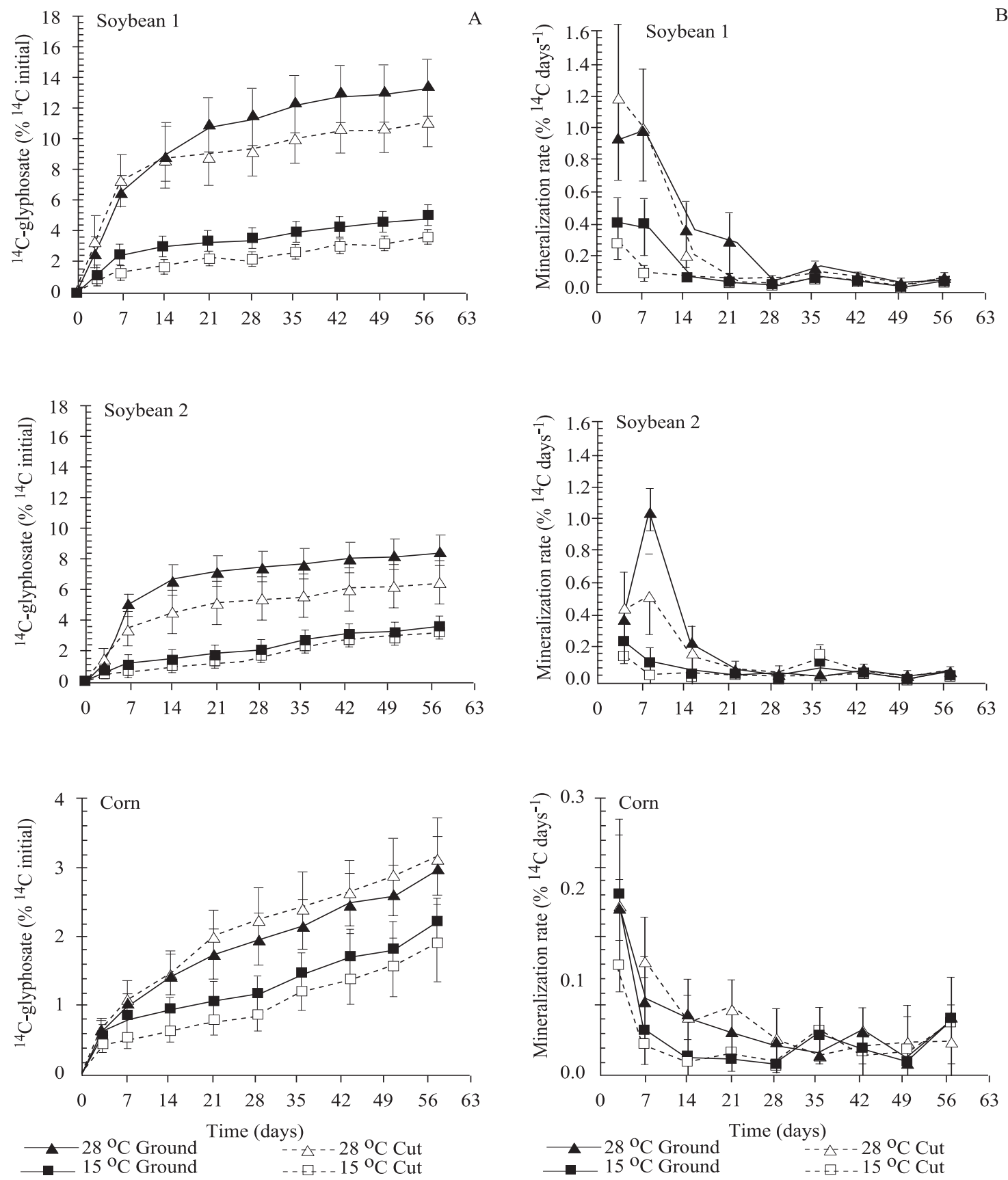

Figure 2. Kinetics (A) and mineralization rates $(B)$ of ${ }^{14} \mathrm{C}$-glyphosate in soybean and corn crop residues. Incubations were carried out at 15 and $28^{\circ} \mathrm{C}$ with Ground $(1 \mathrm{~mm})$ and $\mathrm{Cut}(1$ to $2 \mathrm{~cm})$ residues.

\section{ACKNOWLEDGEMENTS}

This work was funded by the project "Impact des biotechnologies dans les agro-écosystèmes" du Institut National de la Recherche Agronomique,
France. Dr. Rampoldi thanks the Grants Program "Saint Exupéry" and the Sciences and Techniques Secretariat of the Universidad Nacional de Córdoba for their support. 


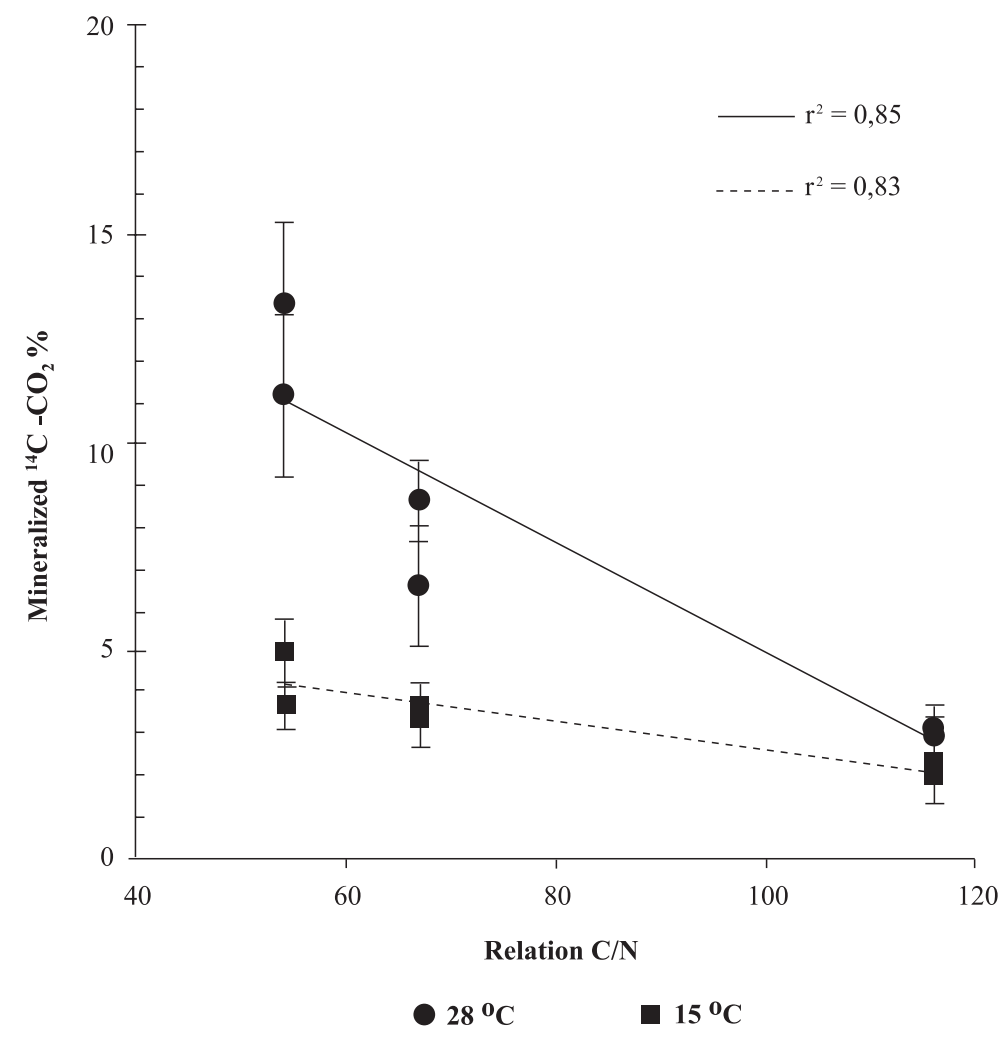

Figure 3. Relationship between percentage of released ${ }^{14} \mathrm{C}-\mathrm{CO}_{2}$ and $\mathrm{C} / \mathrm{N}$ index of two crop residues incubated at two temperatures $\left(15\right.$ and $\left.28{ }^{\circ} \mathrm{C}\right)$.

\section{Mineralización de glifosato: efecto de la temperatura y los residuos vegetales de soya y maíz}

\section{R E S U M E N}

La mineralización es el principal mecanismo de disipación del herbicida glifosato ( $\mathrm{N}$-[fosfonometil] glicina) en el suelo. Existe escasa información sobre el proceso de mineralización de glifosato en el estrato formado por rastrojos en suelos cultivados en sistema de siembra directa. Las muestras de rastrojos de soja (Glycine max L. Merr.) se obtuvieron inmediatamente después de la cosecha (Soja 1) y cuatro meses después de la cosecha (Soja 2) y las de maíz (Zea mays L.) a los tres meses de su cosecha (Maíz). La evolución de ${ }^{14} \mathrm{C}$-glifosato y de la actividad microbiana total (TMA) fue monitoreada por liberación de ${ }^{14} \mathrm{C}-\mathrm{CO}_{2}$ y C- $\mathrm{CO}_{2}$ en condiciones de laboratorio, a dos temperaturas, 15 y $28^{\circ} \mathrm{C}$. El efecto del tamaño de los residuos de cosecha fue evaluado en rastrojo molido (1 $\mathrm{mm}$ ) y cortado (1 a $2 \mathrm{~cm}$ ). A los 56 días de incubación del rastrojo de soja se mineralizó 3,9 y $9,9 \%$ del ${ }^{14} \mathrm{C}$ glifosato inicial aplicado a 15 y $28^{\circ} \mathrm{C}$, respectivamente, mientras que en los rastrojos de maíz la mineralización fue de 2,0 y 3,0\%. Se confirmó la naturaleza cometabólica de la mineralización de glifosato. Se detectó una relación inversa entre la relación $\mathrm{C} / \mathrm{N}$ y el porcentaje de ${ }^{14} \mathrm{C}-\mathrm{CO}_{2}$ liberado. Sobre residuos frescos, con mayor TMA, incrementó la mineralización de glifosato. Aplicaciones de glifosato sobre rastrojos más viejos podrían incrementar la persistencia del herbicida en sistemas de siembra directa.

Palabras clave: glifosato, rastrojo, mineralización, siembra directa, actividad microbiana total. 


\section{LITERATURE CITED}

Accinelli, C. W. C. Koskinen, J. D. Seebinger, A. Party, and M. J. Sadowsky. 2005. Effects of palm incorporated residues on glyphosate mineralization and sorption in soil. J. Agric. Food Chem. 53:110-4117.

Angers, A., and S. Recous. 1997. Decomposition of citrus and at residue as affected by particle size. Plant Soil 189:197-203.

Araujo, A. S. F., R. T. R. Monteiro, and R. B. Abarkeli. 2003. Effect of glyphosate on the microbial activity. Chemosphere 52:799-804.

Bollag, J. M., C. Myers, and R. Minard. 1992. Biological and interactions of pesticides used with soil organic matter. Sci. Total Environ. 123/124:205-217.

CASAFE. 2005. Evolución del mercado fitosanitario argentino. Cámara Argentina de Sanidad Agropecuaria y Fertilizantes (CASAFE), Buenos Aires, Argentina. Disponible en http://www.casafe.org.ar/ m2005.htm Leído 16 May 2006.

Collins, H. P., L. F. Elliot, R. W. Rickman, D. F. Bezdicek, and R. I. Papendick. 1990. Wheat straw decomposition and changes in decomposability during field exposure. Soil Sci. Soc. Am. J. 54:1013-1016.

Cordone, G. E. 1998. Siembra directa. Cuaderno de Actualización Técnica No. 59. p. 16-19. Asociación Argentina de Consorcios Regionales Experimentales Agropecuarios, Buenos Aires, Argentina.

De Jonge, H. L. W. de Jonge, O. H. Jacobsen, T. Yamaguchi, and P. Moldrup. 2001. Glyphosate sorption in soils of diferentes $\mathrm{pH}$ and phosphorus content. Soil Sci. 166:230-238.

De-Neve, S. J. Pannier, and G. Hofman. 1996. Temperature effects on $\mathrm{C}$-and $\mathrm{N}$-mineralization from vegetable crop residues. Plant Soil 181:25-30.

Douglas, C. L., and R. W. Rickman. 1992. Estimating crop residue decomposition rating from air temperature, initial nitrogen content and residue placement. Soil Sci. Soc. Am. J. 56:272-278.

Eberbach, P. 1999. Influence of incubation temperature on the behavior of triethylamine-extractable glyphosate (N-phosphonomethylglycine) in four soils. J. Agric. Food Chem. 47: 2459-2467.

Franz, J. E., M. K. Mao, and J. A. Sikorski (eds.) 1997. Glyphosate: to unique global herbicide. 653 p. ACS Monograph 189. American Chemical Society, Washington DC., USA.

InfoStat. 2006. Grupo Infostat. Universidad Nacional de Córdoba, Facultad de Ciencias Agropecuarias, Córdoba, Argentina.
Jama, B. A., and P. K. R. Nair. 1996. Decomposition-and nitrogen-mineralization patterns of Leucaena leucocephala and Cassia siamea mulch under tropical semiarid conditions in Kenya. Plant Soil 179:275-285.

Johnson, S., J. Herman, A. Mills, and G. Hornberger. 1999. Bioavailability and desorption characteristics of aged, nonextractable atrazine in soil. Environ. Toxicol. Chem. 18:1747-1754.

Kumar, K., and K.M. Goh. 2000. Crop residues and management practices: effects on soil quality, soil nitrogen dynamics, crop yield, and nitrogen recovery. Adv. Agron. 68:197-319.

Mamy, L. 2004. Comparaison des impacts environnementaux des herbicides à large spectre et des herbicides sélectifs: Caractérisation de leur devenir dans le sol et modélisation. 333 p. Tesis doctoral. Institut National Agronomique, Paris-Grignon, France.

Morón, A. 2001. El rol de los rastrojos en la fertilidad del suelo. p. 387-405. In Díaz Roselló, R. (ed.). Siembra directa en el Cono Sur. PROCISUR, Montevideo, Uruguay.

Paul, E.A., and F.E. Clark. 1996. Soil microbiology and biochemistry. Academic Press, Orlando, Florida, USA.

Piccolo, A. G. Celano, M. Arienzo, and A. Mirabella. 1994. Adsorption and desorption of glyphosate in some European soils. J. About. Sci. Health 6:11051115.

Schomberg, H.H., J.L. Steiner, and P.W. Unger. 1994. Decomposition and nitrogen dynamics of crop residues: residue quality and water effects. Soil Sci. Soc. Am. J. 58:372-381.

Sorensen, P. J. N. Ladd, and M. Amato. 1996. Microbial assimilation of ${ }^{14} \mathrm{C}$ of ground and unground plant materials decomposing in a loamy sand and a clay soil. Soil Biol. Biochem. 28:1425-1434.

Strange-Hansen, R., P.E. Holm, O.S. Jacobsen, and C.S. Jacobsen. 2004. Sorption, mineralization and mobility of N-(phosphonomethyl) glycine (glyphosate) in five different types of gravel. Pest Manage. Sci. 60:570-578.

Tian, G., L. Brussaard, and B.T. Kang. 1995. An index for assessing the quality of plant residues and evaluating their effects on soil and crop in the (sub-) humid tropics. Appl. Soil Ecol. 2:25:32. 